\title{
Inflation and Education Expenditure: Evidence from Egypt
}

\author{
Mohamed Maher ${ }^{1 *}$, Yanzhi Zhao ${ }^{2}$ and Chuanzhong Tang ${ }^{3}$ \\ 1.Ph.D. Candidate, School of Public Administration, Dongbei University of Finance and Economics, No. 217 \\ Jian Shan Street, Sha He Kou District, Dalian 116025, China. Assistant Lecturer, Department of Economics, \\ Mansoura University, Algomhoria St., Mansoura 35516, Egypt \\ 2.School of Public Administration, Dongbei University of Finance and Economics, No. 217 Jian Shan Street, Sha \\ He Kou District, Dalian 116025, China \\ 3.International Business College, Dongbei University of Finance and Economics, No. 217 Jian Shan Street, Sha \\ He Kou District, Dalian 116025, China \\ * E-mail of the corresponding author: econ3mmohamed@gmail.com,mohamed_maher16961737@mans.edu.eg
}

Acknowledgment: This article is a part of the Ph.D. dissertation of the first author (Mohamed Maher).

\section{Abstract}

For Egypt, there are no previous studies, at any time, that investigate the impact of changes in inflation on education expenditure. In addition, previous studies do not handle endogeneity while estimating the inflationeducation expenditure model. Therefore, this paper empirically investigates the relationship between inflation and education expenditure in Egypt (1976-2019). Correcting for the potential endogeneity, the GMM model has been conducted. Our findings reveal that inflation plays a fundamental role in explaining education expenditure per student in Egypt. That is, rising inflation has a deleterious effect on education expenditure. Moreover, there is no significant crowding-out effect among education expenditure and the rival expenditure programs in the Egyptian government's budget. Finally, we suggest policymakers to keep inflation rates low to avoid their deleterious effects on education expenditure.

Keywords: Education expenditure, Inflation, Egypt, Kapetanios unit root test, Structural breaks

DOI: $10.7176 / \mathrm{JESD} / 13-4-07$

Publication date: February $28^{\text {th }} 2022$

\section{Introduction}

Education is one of the main fundamental pillars for human capital and, hence, development strategy. Education improves workers' cognitive and non-cognitive skills, resulting in increased productivity. In today's labor market, education is crucial. Numerous studies from various countries and periods have found that those with more education get higher earnings, have lower unemployment rates, and work in more prominent occupations than those with less education. Despite abundant evidence of a positive relationship between education and labor market status, social scientists have been hesitant to draw firm conclusions regarding schooling's causal effect. Growth accounting exercises discovered that rising education levels could explain much of the postwar US productivity growth, leaving little opportunity for technical change, piqued economists' interest in this subject in the late $1950 \mathrm{~s}$ (Card, 1999; Downes, 2001; Sagarik, 2013).

Our study aims at empirically estimating the effect of increased inflation rates on education expenditure (those amounts of money devoted to the education process) in the Egyptian context. In such a relationship, higher inflation rates result in a decline in real income devoted to education purposes. Berg (1981) ascertains that inflation might benefit or hinder the education process through benefiting or hindering education expenditure. In this context, expenditure on education is considered one of the fundamental determinants of education quality. Inflation led most public educational institutions to raise their tuition fees. This, in turn, helped correct some of the price imbalances between public and private educational institutions. On the other hand, inflation in research costs has forced many researchers to reduce research undertakings by pushing them to submit significantly smaller budgets to funding agencies. It diminishes the purchasing power of savings for students and their parents. Furthermore, salary increases and other outlays for research have failed to keep pace with inflation since inflation has corrosive effects on faculty salaries and middle-class students' parents. Berg considers inflation as an off-budget expenditure tax levied, declining the real amounts of money directed to education, especially higher education.

Bowen (1975) argues that inflation highlights a much more significant inflationary impact on higher education costs than on the economy as a whole. This finding is attributed to the long-term trend for tuition fees to increase more than inflation in general - a phenomenon owing to higher education's labor-intensity and the greater difficulties in generating productivity gains in education than in the economy. A significant degree of inflation and a substantial amount of unemployment simultaneously with attendant declines in real income have a tremendously detrimental impact on the revenues and expenditure sides of our budgets and, of course, on education expenditures and its revenues. In such a situation, the burden of tuition fees, for instance, is much harder for parents and students to bear.

According to Swan (1967), there are two ways monetary policy could affect education. First, the effect of 
inflation on education expenditure. Second, the monetary policy stance (expansionary or tightening) and its effect on the credit available for students' loans. Besides, tight monetary policy necessitates a reduction in planned expenditures, including education's. As maintained by Swan (1967), other than parental income and educational endowment, there are other ways to pay for schooling funding (tuition fees). Long-term credit offered by commercial banks to students in higher education is one of these sources. In this regard, monetary policy can affect the banks' ability to provide loans for financing students loans. In this respect, if market interest rates, paid on the students' loans, rise above the ceiling rate - a maximum interest rate payable on the loans - these loans become a less profitable investment alternative. We would say that Swan (1967) shows us how education expenditure could be financed theoretically through students' loans but, at the same time, concerning the Egyptian context, public education is a de jure free of charge, and private education is available only for the wealthiest.

Regarding the effect of inflation on education expenditure, the price elasticity of education expenditure reflects how people and government respond to prices movements. This elasticity is expressed by the coefficient on inflation in the education expenditure regression. It is expected to be negative and less than one, reflecting the necessity of education for people and development. Guo and Alexander (2006) and Narayan et al. (2009) argue that the escalating expense of schooling has prompted a high degree of precautionary savings since the $1990 \mathrm{~s}$. According to a poll, 29\% of Chinese families have purchased educational insurance policies, $43 \%$ have opened specialized education savings accounts, and 38\% have modified their consumption behavior to save more for schooling.

Based on our earlier discussion and the contradiction among previous studies concerning the association between education expenditure and inflation, the main research question for this sub-model can be stated as: Is there a deleterious effect of increasing inflation on education expenditure and hence welfare and development?

6.0

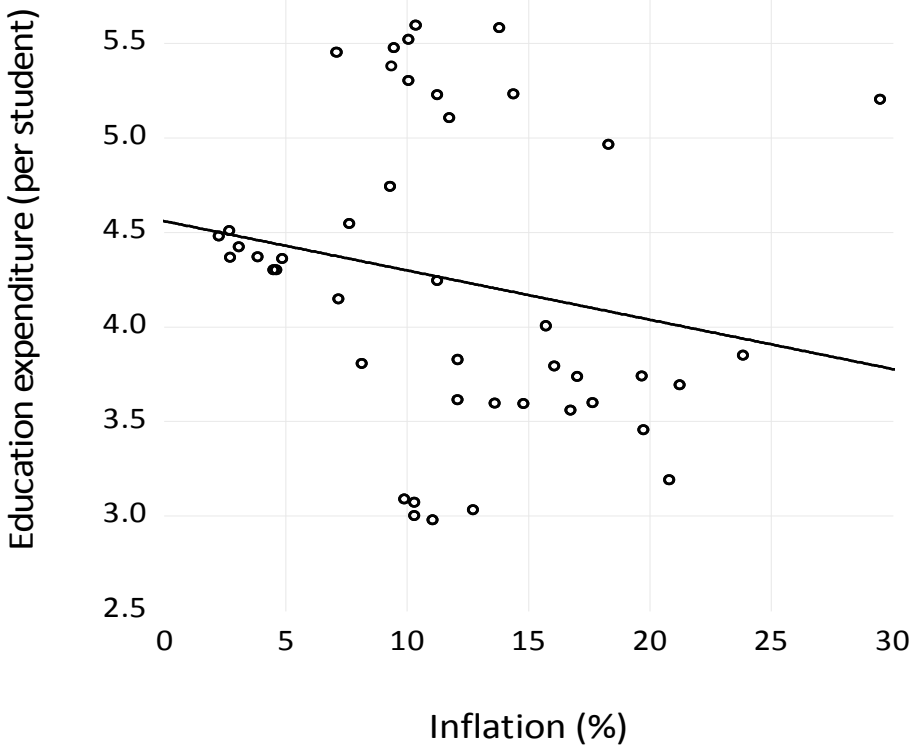

Figure 1. Inflation and education expenditure in Egypt

Note: The solid line indicates the negative relationship between both variables in Egypt.

The importance of this study comes as an attempt to fill the gap regarding investigating the relationship between inflation and education expenditure (per student) in Egypt generally, and in particular over the period (1976-2019). Figure 1 exhibits the relationship between CPI inflation and education expenditure (per student) in Egypt over the study period. The figure depicts that there is a negative relationship between both variables. As inflation increases, education expenditure decreases.

Taken as an implication of the deleterious effects of inflation on the economic development, the relationship between inflation and education expenditure is investigated in this paper. The generalized method of moments (GMM) and instrumental variable (IVs) techniques are conducted for robustness and to handle endogeneity. Moreover, many conventional unit root tests have been used to check the stationarity of the variables, alongside the Kapetanios unit root test with structural breaks.

Overall, our study attempts to verify the effects of inflation rate on education expenditure in Egypt. The literature investigating the relationship between inflation and education expenditure in different economies and periods has been reviewed in Section 2. The remaining of this sub-model is as follows: Section 3 exhibits data specifications and sources and the variables description. Section 4 shows different unit root tests. Section 5 
explains the GMM model used to estimate and analyze the results of the relationship between both variables. Section 6 discusses the results and Section 7 concludes.

\section{Literature review and hypothesis development}

Many studies have investigated the determinants of education expenditures, and especially the effect of inflation. Sagarik (2013) reveals that inflation affects total and current education expenditure negatively in Thailand during the period 1982-2010, implying that as inflation increases, total education expenditure decreases. This effect is attributed to the Keynesian countercyclical theory that inflation has an inverse effect on government expenditure, and particularly the total education expenditure (as one of the social government expenditure). To sustain the same level of education quality through high inflation times, the government may consider raising education spending. When education expenditures do not rise in lockstep with inflationary pressures, the impact of inflation can be observed.

In the light of the inverse relationship between inflation and spending on education, more recently, Sequeira (2021) emphasizes the negative relationship between inflation on the one hand and both economic growth and welfare losses on the other hand by mediating spending on education. This indicates that the expansionary monetary policy that departs from high inflation may include gains in terms of growth and welfare. Furthermore, he connects the dynamics to obtain the diminishing, limited, and nonlinear effects of inflation on both long-run growth and household cash needed for education (tuition fees). He points out that the impact of monetary policy on economic growth is associated with the reallocation of money from the goods-producing sector to education. As well, he assures that the more cash households would keep financing education, the more significant the negative impact of inflation on real GDP growth. Furthermore, in a high-inflation setting, a rise in household education costs may have a more severe impact on economic growth owing to the deleterious impacts on the education process as an engine for human capital and hence economic development.

Zhang and $\mathrm{Ou}$ (2013) find that inflation negatively affects education and culture services expenditures (as forms of investment in human capital). With reference to the price elasticity of demand for education, they found that education expenditure is inelastic, indicating that people continue to spend on education even if the price rises substantially.

In contrast, using data on the Malaysian economy from 1982 to 2016, Yun and Yusoff (2018) reveal that inflation affects education expenditure positively in the long run. Still, this relationship turned negative in the short run since high inflation reduces parents' capabilities to afford high school tuition fees and other education costs. As a result, the government must act by allocating additional funding to the education sector, ensuring that no citizen is denied access to education. The fact that the determinants of public education spending shift over time were expressed in the different outcomes of the short- and long-run. Furthermore, they claimed that inflation is the most significant element that accounts for the bulk of education budget shocks.

In the same context, using panel data for 84 countries from 1965 to 2004, Yilmazkuday (2013) concludes that human capital (proxied by education) has a positive and significant effect on economic growth when inflation is below a certain threshold. Besides, using data on 21 advanced countries over the period 1980-2001, Busemeyer (2007) finds that the level of economic development (proxied by GDP per capita ${ }^{1}$ ), the young population, the level of governmental social expenditure, among others, are the main determinants of public education expenditure in the advanced countries. In addition, Ram (1995a), Hanushek and Rivkin (1996), and Fernandez and Rogerson (1997) concentrate on the effects of socioeconomic variables such as education enrollment rate, teacher numbers, and per capita GDP. They also ascertain that increases in staffing costs and outside spending, as well as the improvements in social school enrollment, have a significant impact on education spending.

As stated in this section, as well as what we discuss in the Introduction, the relationship between inflation and education expenditure has been examined in some prior research, especially for developed economies. However, to the best of our knowledge, investigating such a relationship is still highly scarce for developing countries. The results are mixed: Some found a negative relationship between both variables, and others found a positive relationship.

For Egypt, in particular, there are no previous studies, at any time, that investigated the impact of changes in inflation on education expenditure. The prior studies mentioned earlier did not handle endogeneity while estimating the inflation-education expenditure model. Therefore, this current study, to the best of the researcher's knowledge, is the first study to examine how inflation can affect education expenditure in Egypt. As well, this study uses the GMM technique in analyzing such a relationship to overcome the reverse causality problem (as a source of endogeneity). Furthermore, the overwhelming majority of the empirical evidence obtained from developed and developing countries reports somewhat mixed and inconsistent results. Given the limitations above in prior research, this current study tends to overcome these shortcomings by examining the impact of the inflation rate on education expenditure in Egypt over the period (1976-2019).

\footnotetext{
${ }^{1}$ It is calculated by dividing the GDP in constant prices by the total population in a specific country.
} 
The current study considers the nature of the relationship between inflation and education expenditure in Egypt, as well as the fact that literature on the relationship between both variables yields mixed results. Accordingly, based on the arguments of education expenditure, empirical results of prior research reviewed earlier, and the Egyptian environment over the study period, the fourth hypothesis can be formulated in the following way: There is a negative relationship between inflation and education expenditure in Egypt. To estimate, analyze, and investigates the effect of inflation variability on education expenditure. Related to this sub-objective, we pursue to analyze the association between inflation and education expenditure in Egypt.

\section{Data description and the variables}

The relationship between inflation and education expenditure is affected or controlled by some other macroeconomic and social variables; they are called control variables. The researcher's choice for these variables is subject to what is indicated and used by education expenditure literature [some of them are reviewed earlier, e.g., Sagarik (2013) and Yun and Yusoff (2018)]. Including these variables within the model increases the strength of the relationship between the two main study variables [i.e., inflation $(\pi)$ and education expenditure (EDU_CAP)]. The proposed model introduces inflation as the fundamental independent variable. For robustness, we use a set of those variables as described in Table 1 . Therefore, the education expenditure proposed model takes the form

$$
\begin{aligned}
\Delta \log E D U_{-} C A P_{t}=\beta_{0} & +\beta_{1} \pi_{t}+\beta_{2} \Delta \log G D P_{-} C A P_{t}+\beta_{3} E_{N R O L_{t}}+\beta_{4} \Delta \log G F C F_{t} \\
& +\beta_{5} \Delta \log G O V_{-} C O N S_{t}+\varepsilon_{t}
\end{aligned}
$$

\begin{tabular}{|c|c|c|}
\hline Variable & Acronym & Definition \\
\hline $\begin{array}{l}\text { Education } \\
\text { expenditure } \\
\text { per capita }\end{array}$ & $\log$ EDU_CAP & $\begin{array}{l}\text { - It refers to the total amounts of money the government devotes to spending } \\
\text { on education purposes in the different education levels. It covers public and } \\
\text { private educational institutions such as universities, institutions, and } \\
\text { schools. Spending comprises educational institutions' instruction and } \\
\text { auxiliary services for students. } \\
\text { - To calculate the per capita (per student) education expenditure, we divide } \\
\text { total education expenditure by population aged 5-19, as in Fernandez and } \\
\text { Rogerson (1997) and Morgan et al. (2001). This variable is expressed in its } \\
\text { logarithmic form for modelling purposes. }\end{array}$ \\
\hline Inflation rate & $\pi$ & $\begin{array}{l}\text { - It is defined as the yearly change in the CPI. } \\
\text { - It is expected to affect education expenditure (per capita) negatively, as an } \\
\text { increase in inflation rates decreases the purchasing power of amounts of } \\
\text { money devoted to being spent on educational purposes. }\end{array}$ \\
\hline $\begin{array}{l}\text { GDP per } \\
\text { capita }\end{array}$ & $\log$ GDP_CAP & $\begin{array}{l}\text { - GDP per capita is incorporated as a proxy for the level of economic } \\
\text { development or the level of national income in the country, as in Juhn and } \\
\text { Mauro (2002) and Rodrik (2008). } \\
\text { - To calculate it, we divide GDP in constant prices (real GDP) by total } \\
\text { population. This variable has been used extensively in the literature instead } \\
\text { of GDP, for example, Sagarik (2013), Ram (1995b), and Busemeyer (2007). } \\
\text { - It is expected to affect education expenditure (per capita) positively, as an } \\
\text { increase in national income increases the people's purchasing power, and } \\
\text { hence, their consumption levels, including the amounts of money people } \\
\text { devoted to being spent on educational purposes. }\end{array}$ \\
\hline
\end{tabular}

Table 1. Data description and the variables definition 


\begin{tabular}{lll}
\hline \multicolumn{1}{c}{ Variable } & Acronym & \multicolumn{1}{c}{ Definition } \\
\hline $\begin{array}{l}\text { Education } \\
\text { enrollment } \\
\text { rate }\end{array}$ & ENROL & $\begin{array}{l}\text { Fernandez and Rogerson (1997) included the students' enrollment rate in } \\
\text { different educational stages as an independent variable in their education } \\
\text { expenditure model. Their dependent variable is the spending per student; } \\
\text { then, they obtained a negative sign on the coefficient of enrollment rate. } \\
\text { Also, Hanushek and Rivkin (1996) and Sagarik (2013) use the enrollment } \\
\text { rate, as an explanatory variable, calculated as }\end{array}$ \\
& \\
& & \\
& & \\
& &
\end{tabular}

Note: Source of all data set is the World bank's WDI database.

\section{Technical Procedures}

4.1. Multicollinearity and descriptive statistics

We tested for the presence of multicollinearity among regressors using the pairwise correlation matrix. Wooldridge $(2020$, p. 92) note that a correlation coefficient greater than 0.8 indicates severe multicollinearity. Therefore, Table 2 reveals no strong correlation among the independent variables. The descriptive statistics of the variables, shown in Table 3, highlight that the standard deviation for the Inflation and ENROL series is high. Contrarily, the volatility of the other four series is relatively low. Also, the maximum and minimum values indicate a relatively large dispersion of inflation values. The mean is lower than median for all study variables, except the Inflation series, indicating that the distribution of the data has a negative skew. In this case, the distribution of the variables is asymmetrical. If skewness and kurtosis decrease, the Jarque-Bera (JB) test statistic decreases, indicating that the series becomes closer to the normal distribution.

The identical normal distribution implies that a series has a skewness equals zero, and kurtosis equals 3 . Consequently, the JB test statistic equals zero. The JB's null hypothesis is that the series follows a normal distribution (Wooldridge, 2020, ch. 5). Besides, all the series are normally distributed, except $\triangle \log E D U \_C A P$ and $\triangle \log G O V$ CONS.

Table 2. Matrix of correlations for the regressors

\begin{tabular}{lccccc}
\hline Regressors & $\pi$ & $\begin{array}{c}\Delta \log \\
\text { GDP_CAP }\end{array}$ & ENROL & $\Delta \log$ GFCF & $\Delta \log$ GOV_CONS \\
\hline Inflation $(\pi)$ & 1.000 & & & & \\
$\Delta \log$ GDP_CAP & 0.060 & 1.000 & & & \\
ENROL & -0.193 & 0.074 & 1.000 & & \\
$\Delta \log$ GFCF & -0.300 & -0.103 & 0.085 & 1.000 & \\
$\Delta \log$ GOV_CONS & 0.087 & -0.010 & 0.011 & 0.016 & 1.000 \\
\hline
\end{tabular}


Table 3. Descriptive statistics

\begin{tabular}{lcrrrrr}
\hline Series & $\Delta \log$ EDU_CAP & \multicolumn{1}{c}{$\pi$} & $\Delta \log$ GDP_CAP & \multicolumn{1}{c}{ ENROL } & \multicolumn{1}{c}{$\Delta \log$ GFCF } & $\Delta \log$ GOV_CONS \\
\hline Mean & 0.055838 & 11.89590 & -0.000694 & 31.52142 & 0.003457 & 0.038686 \\
Median & 0.075243 & 11.17164 & 0.003058 & 32.02184 & 0.007388 & 0.043549 \\
Maximum & 0.522906 & 29.50661 & 0.050337 & 38.07588 & 0.469413 & 0.080806 \\
Minimum & -0.377321 & 2.269757 & -0.045218 & 23.17350 & -0.386978 & -0.037238 \\
Std. dev. & 0.143947 & 6.096446 & 0.020981 & 4.295272 & 0.168149 & 0.023188 \\
Skewness & 0.029640 & 0.556107 & -0.140724 & -0.319334 & -0.017546 & -1.124916 \\
Kurtosis & 5.383946 & 3.202445 & 3.334801 & 2.168148 & 3.467655 & 5.046115 \\
JB & 9.951748 & 2.343011 & 0.334784 & 1.924781 & 0.384882 & 16.18458 \\
JB Prob. & 0.006902 & 0.309900 & 0.845868 & 0.381979 & 0.824943 & 0.000306 \\
\hline
\end{tabular}

\subsection{Unit root tests}

\subsubsection{Conventional unit root tests}

To proceed with the GMM technique, we must satisfy the stationarity assumption. It indicates that a variable, say $x$, should not exhibit any form of non-stationarity. To handle non-stationarity, we have to use some transformations, like the first-difference (Creamer and Botha, 2017; Mátyás et al., 1999; Ogaki, 1993). In this respect, for the GMM and IVs to be consistent, we have to ensure that all of our main variables, control variables, and instruments are stationary, i.e., integrated in levels or I(0) (Clarida et al., 1998; Ege Yazgan and Yilmazkuday, 2007; Han, 2012; Hansen, 1982). To this end, we use a battery of the unit root test. We start with the conventional unit root tests (without considering the structural breaks), such as the augmented Dickey-Fuller (ADF) test of Dickey and Fuller (1981), the Phillips-Perron (PP) unit root test of Phillips and Perron (1988), and the Kwiatkowski, Phillips, Schmidt, and Shin (KPSS) test of Kwiatkowski et al. (1992). It is worth emphasizing that, unlike the null hypothesis of both the ADF and PP tests, the null hypothesis $\left(\mathrm{H}_{0}\right)$ of the KPSS test states that the series has no unit root.

Table 4. Conventional unit root tests for Education Expenditure's model

\begin{tabular}{|c|c|c|c|c|c|c|c|c|c|}
\hline \multirow[b]{2}{*}{ Series } & \multicolumn{2}{|c|}{ ADF test-statistics } & \multicolumn{2}{|c|}{ PP test-statistics } & \multicolumn{3}{|c|}{ KPSS test-statistics } & \multirow[b]{2}{*}{$k$} & \multirow[b]{2}{*}{ Result } \\
\hline & Level & $\begin{array}{c}1^{s t} \\
\text { difference }\end{array}$ & Level & $\begin{array}{c}1^{\text {st }} \\
\text { difference }\end{array}$ & Level & $\begin{array}{c}1^{\text {st }} \\
\text { difference }\end{array}$ & $\begin{array}{c}5 \% \\
\text { critical } \\
\text { values }\end{array}$ & & \\
\hline $\log$ EDU_CAP & -2.6552 & .3882 & -2.2106 & $.0655 * * *$ & $0.1313^{\mathrm{A}}$ & $0.0561^{\mathrm{A}}$ & 0.4630 & 1 & Contr. \\
\hline Inflation $(\pi)$ & -0.5232 & $-4.8068 * * *$ & -1.1428 & $-10.534 * * *$ & $0.3104^{\mathrm{A}}$ & $0.0618^{\mathrm{A}}$ & 0.4630 & 2 & Contr. \\
\hline $\log$ GDP_CAP & -2.8432 & $-2.7654 *$ & -3.1050 & $-4.1600 * * *$ & $0.2291 \mathrm{~A}$ & 0.5192 & 0.4630 & 1 & Contr. \\
\hline ENROL & -2.8330 & $-6.3791 * * *$ & $-3.9089 * *$ & $-8.7542 * * *$ & 0.1586 & $0.0489^{\mathrm{A}}$ & 0.1460 & 2 & Contr. \\
\hline $\log \mathrm{GFCF}$ & $-3.3398 *$ & $-2.8916 * * *$ & -2.6815 & $-3.7770 * * *$ & $0.1146^{\mathrm{A}}$ & $0.1338^{\mathrm{A}}$ & 0.1460 & 1 & Contr. \\
\hline $\begin{array}{l}\log \\
\text { GOV CONS }\end{array}$ & 5.2959 & -2.1271 & 10.9773 & $-5.7254 * * *$ & 1.5496 & $0.1385^{\mathrm{A}}$ & 0.4630 & 2 & Contr. \\
\hline
\end{tabular}

Notes:

- $* * *, * *$, and $*$ denote the $1 \%, 5 \%$, and $10 \%$ levels of significance, respectively.

- We used the MAIC to assign the number of lags we needed to perform the ADF unit root test. The maximum number of lags is 3 lags. $k$ is the lag length determined based on the MAIC criterion.

- Contr.: There is a conflict between the three tests concerning whether the series is stationary or not.

${ }^{A}$ indicates that the series is stationary based on the KPSS test.

- The constant is significant for all variables except for log GOV_CONS. The trend is significant for all variables except for log EDU_CAP and log GOV_CONS.

4.2.2. Kapetanios unit root test

All of the unit root tests illustrated above have poor power if structural breaks exist in the data generating process (DGP), and they could lead to us making false and biased inferences regarding time-series stationarity. Additionally, the presence of structural breaks could result in spurious cointegration and misleading estimations. When the first differenced series has a substantial and negative moving average component to the residuals, some of these tests, particularly the PP test, suffer from severe size distortions. (Choi, 2015, pp. 28-29; Ng \& Perron, 2001; Shrestha \& Bhatta, 2018).

Taking the structural breaks into account, we perform the Kapetanios (2005) unit root test. It examines the stationarity in the intercept and/or trend when there are up to five unknown structural breaks. We allow for only two structural breaks due to small sample size. Table 5 highlights the results of Kapetanios test, revealing the contradiction between its results and those of the conventional unit root tests. This test shows that some of our variables are stationary, at the 5\% significance level, and others are $I(1)$ around two structural breaks. Due to the non-stationarity of some variables in level, following Juhro et al. (2021), we differenced nonstationary variables 
(i.e., $\log G D P C A P, \log G F C F$, and $\log G O V C O N S$ ) to be stationary before estimating our model. Table 5. Kapetanios unit-root test with structural breaks

\begin{tabular}{|c|c|c|c|c|c|c|c|c|c|}
\hline \multirow[b]{2}{*}{ Series } & \multicolumn{3}{|c|}{ Test statistics } & \multicolumn{2}{|c|}{$5 \%$ critical values } & \multirow{2}{*}{\begin{tabular}{|c|} 
Constant \\
(C) \\
or \\
Trend (T)
\end{tabular}} & \multirow[b]{2}{*}{$I(\mathrm{~d})$} & \multirow[b]{2}{*}{ Result } & Break dates \\
\hline & Level & $\begin{array}{c}1^{\text {st }} \\
\text { difference }\end{array}$ & $\begin{array}{c}2^{\text {nd }} \\
\text { difference }\end{array}$ & Constant & $\begin{array}{l}\text { Constant } \\
\& \text { Trend }\end{array}$ & & & & $\begin{array}{cc}1^{\text {st }} & 2^{\text {nd }} \\
\text { break } & \text { break }\end{array}$ \\
\hline $\log$ EDU_CAP & -3.5867 & $-5.2825 * *$ & $-8.3970 * *$ & -5.096 & -6.113 & $\mathrm{C}, \mathrm{T} \& \mathrm{C}$ & $I(1)$ & Non & 19862009 \\
\hline Inflation $(\pi)$ & $-6.2678 * *$ & $-6.4128 * *$ & $-8.3217 * *$ & -5.096 & -6.113 & $\mathrm{C}, \mathrm{C}$ & $I(0)$ & Stat. & 19892001 \\
\hline log GDP_CAP & -3.8887 & -2.8931 & $-12.109 * *$ & -5.096 & -6.113 & $\mathrm{C}, \mathrm{T} \& \mathrm{C}$ & $I(2)$ & Non & 19842005 \\
\hline ENROL & $-6.8139 * *$ & $-8.5096 * *$ & $-8.9351 * *$ & -5.096 & -6.113 & $\mathrm{C}, \mathrm{T} \& \mathrm{C}$ & $I(0)$ & Stat. & 19912004 \\
\hline $\log \mathrm{GFCF}$ & -4.2014 & -4.8005 & $-9.3560 * *$ & -5.096 & -6.113 & $\mathrm{C}, \mathrm{T} \& \mathrm{C}$ & $I(2)$ & Non & 19862006 \\
\hline $\begin{array}{l}\log \\
\mathrm{GOV} \text { CONS }\end{array}$ & -4.2883 & $-6.8086^{* *}$ & $-9.2707 * *$ & -5.096 & -6.113 & $\mathrm{C}, \mathrm{C}$ & $I(1)$ & Non & 19942007 \\
\hline
\end{tabular}

Notes:

- ** denotes the 5\% level of significance.

- The trimming parameter is set to 0.15 .

- We use the same number of lags for every variable shown in conventional ADF, PP, KPSS unit root tests.

- The letter ordered first, in the notation $(C, T \& C)$ refers to the significance of constant and trend terms for both levels and first differences, respectively, separated by (\&).

- Non: Non-stationary series at 5\% significance level and needs to be differenced. Stat.: Stationary series at 5\%.

- I(d) denotes the integration order. I(0) indicates the stationary series at level. I(1) denotes the stationary series of order one. I(2) denotes the stationary series of order two.

\section{GMM Technique, Explained}

The GMM estimation procedure was first proposed by Hansen (1982) to deal with the potential reverse causation. Reverse causation, as one of the reasons for endogeneity, arises when the dependent variable and it may be attributed to measurement errors in the variables (Judd and Rudebusch, 1998; Leszczensky and Wolbring, 2019; Ullah et al., 2018). Bond et al. (2001) emphasize that the explanatory variables are generally endogenous and measured with error. They show that using instrumental variables potentially provides consistent estimation even in the existence of measurement error. Besides, it may be attributed to omitting critical independent variables that become represented as a part of the random error term, and hence affect both the dependent and independent variables. The ordinary least squares (OLS) technique requires that the error term has a mean of zero, and that the explanatory variables are uncorrelated with the error term, which is called the "orthogonality assumption". The existence of such endogeneeity produces biased estimator for our core parameter, making its estimate inconsistent for the true parameter value. Therefore, the GMM estimator is adopted primarily to correct for this problem and to produce more efficient and consistent estimators; besides, it is generally better under heteroscedasticity and serial correlation (Altinger, 2002; Hamilton, 1994, p. 416; Wooldridge, 2001).

Unlike many other estimation procedures, the GMM estimator does not require the normality assumption and the full density. Rather, it pays great attention to satisfying the orthogonality condition or the moment conditions, ruling out the model misspecification (Hamilton, 1994, p. 409). According to Stock and Watson (2020, ch. 19), Roodman (2009b), and Kennedy (2008, pp. 134-135), the GMM estimation process encompasses two stages. A consistent estimating procedure is performed to provide a preliminary estimate of the parameters in the first step. These are relied upon by obtaining the residuals, which are then used to estimate the unknown asymptotic variance-covariance matrix of the error term, called the weighting matrix, $\Omega$. In the second step, the estimate of $\Omega$ is entered into the objective function which the GMM estimator attempts to minimize, making it as small as possible. The GMM framework estimate the coefficients by minimizing the sample covariance between the error term and the exogenous variables.

In the context of conducting GMM, we have to signify our instruments set. The primary idea behind instrumental variables regression is to separate the 'good' variation in the endogenous explanatory variable (the part that is orthogonal to the error term) from the 'bad' one (the part that is correlated to the error term). According to Stock and Watson $(2020$, ch. 12), instrumental variables are used as additional variables to disentangle the movements in the explanatory variable that is orthogonal to the error term. Those instruments come from outside the equation to be estimated. Altinger (2002) proposes that any lagged variables that assist in predicting, say, for instance, inflation and the output gap, as independent variables, can serve as a possible instrument. Besides, any current variables that are uncorrelated with the disturbance term can serve as an instrument. One can choose the combination of those instrumental variables that have the highest correlation with the main explanatory variables.

For estimating the primary structural model, we follow two stages. In the first stage, the endogenous variable or the instrumented variable $X$ is regressed on the instrumental variable(s) besides other explanatory variables, if 
any, in order to estimate the predicted value of the endogenous variable ( $\hat{X}$ ). In the second stage, we use the estimated or predicted values ( $\hat{X}$ ), obtained from the first-stage equation, rather than its actual values since $\hat{X}$ is uncorrelated with the error term of the main structural model, denoted $\varepsilon$. The second stage regression model can be shown as $Y=\hat{X} \beta+\varepsilon$. The estimated coefficients from the second stage are assumed to be unbiased, producing consistent results.

In the context of the GMM procedure, we should assign our instruments set that satisfies the orthogonality conditions, discussed before, to be valid instruments. That is, (1) Instrumental variables must be orthogonal to the error term; (2) Instrumental variables must be strongly and sufficiently correlated with the endogenous regressors; (3) Instrumental variables should not affect the dependent variable directly, but rather through its effect on the explanatory variables; and (4) The number of the instrumental variables should outweigh the number of the unknown parameters to be estimated (overidentification); that is, at least one instrument for each endogenous variable.

\subsection{Instruments set}

The relationships between economic and social variables are theoretically endogenous (e.g., the presence of reverse causality). The socio-economic control variables included in the education expenditure model suffer from endogeneity. Consequently, we need to use a technique to distinguish those effects and handle such an issue. Unlike OLS, GMM models and IVs technique can do it. Arellano and Bond (1991) and Arellano and Bover (1995) ascertain the effectiveness of the GMM procedure to handle these problems, reinforcing the robustness and strength of the estimation process. Besides endogeneity, it is common for economic models to suffer from econometric problems like serial correlation and heteroskedasticity of residuals. That is why, as we show later, we use the Newey-West HAC nonparametric estimators, advocated by Newey and West (1987), with the Bartlett kernel spectral density estimator and fixed bandwidth. To estimate the previous specification of the education expenditure model in Egypt using the GMM procedure, we should first define the set of orthogonality condition as

$$
\begin{aligned}
\mathrm{E}_{t}=\{[ & {\left[\Delta \log E D U_{-} C A P_{t}-\beta_{0}-\beta_{1} \pi_{t}-\beta_{2} \Delta \log G D P_{-} C A P_{t}-\beta_{3} E N R O L_{t}-\beta_{4} \Delta \log G F C F_{t}-\beta_{5} \Delta \log \right.} \\
& \left.\left.G O V_{-} C O N S_{t}\right], z_{t}\right\}=0,
\end{aligned}
$$

where $\mathrm{E}_{t}$ denotes the expected value, and $z_{t}$ represents the instruments set. The term $[\cdot]$ refers to the error term.

Based on a survey for the literature mentioned above, our instruments set consists of: One lag of the differenced dependent variable (education expenditure per capita), one lag of inflation rate, ${ }^{1}$ one lag of interest rate and nominal exchange rate as an instrument for inflation rate, one lag of the differenced GDP per capita, one lag of the education enrollment rate, one lag of the differenced GFCF, one lag of the differenced GOV_CONS. Besides, the year 2017 is included as a dummy proposed by the structural change in the Egyptian economy related to the hike in inflation rate after floating the Egyptian pound's exchange rate by the end of 2016. Additionally, the constant term is included because it is orthogonal to any random variables, following Hong (2020).

\subsection{Sargan and Hansen Tests}

To test whether an instrumental variable is correlated with the error term (the orthogonality condition), we use the Sargan test of Sargan $(1958,1959)$. Its null hypothesis $\left(\mathrm{H}_{0}\right)$ states that all instruments are not correlated with the disturbance term, or that all overidentifying instrumental variables are jointly valid. When failing to reject $\mathrm{H}_{0}$, it should be noted that this does not necessarily imply that all instruments are valid. Roodman (2009b) and Hall (2005, pp. 45-46) articulate that Hansen $J$ test of Hansen (1982) is considered as an extension to Sargan $C$ test. The $J$ statistic is testing for overidentifying restriction or testing for endogenous instruments. It determines how close the sample is to fulfilling the overidentification restrictions, under the null hypothesis that the instruments are orthogonal to the error terms. It can also test for structural specification (Mavroeidis, 2005; Roodman, 2009a).

\section{GMM results and discussion}

Table 6 reports the results of the GMM model's estimates for education expenditure in Egypt over 1976-2019. Our GMM estimates reveal a statistically significant negative relationship between inflation and education expenditure per student at the $1 \%$ significance level (equals $\beta_{1}=-1.418$; $p$-value $<0.01$ ). In other words, inflation plays a fundamental role in explaining education expenditure per capita in Egypt. Holding all other explanatory variables constant, if inflation increases by one percent, it is expected that education expenditure per student will decrease by approximately 1.42 percent. This result is consistent with the economic theory and the literature; for example, Ihugba et al. (2019). Using annual data over the period 1970-2017, they conclude that inflation hinders

\footnotetext{
${ }^{1}$ According to Hong (2020), we can use lagged values of explanatory variables as instruments. Kennedy (2008, ch. 9) clears that it is desirable to include at least two more instrumental variables than endogenous variables.
} 
education, and hence, human capital development in Nigeria.

Table 6. GMM estimates of Education Expenditure model for Egypt (1976-2019)

\begin{tabular}{|c|c|c|c|c|}
\hline & & & & \\
\hline Regressors & Coefficient & Std. error & $t$-Statistic & $p$-Value \\
\hline Inflation $(\pi)$ & -1.4184 & 0.5969 & -2.3765 & $0.0070 * * *$ \\
\hline$\Delta \log$ GDP_CAP & 1.8335 & 0.5853 & 3.1324 & $0.0035 * * *$ \\
\hline ENROL & -0.0130 & 0.0025 & -5.1044 & $0.0000 * * *$ \\
\hline$\Delta \log \mathrm{GFCF}$ & -0.0556 & 0.1433 & -0.3882 & 0.7003 \\
\hline$\Delta \log$ GOV_CONS & -2.5545 & 1.7565 & -1.4543 & 0.1548 \\
\hline Constant $\left(\overline{\beta_{0}}\right)$ & 0.7421 & 0.2009 & 3.6945 & $0.0007 * * *$ \\
\hline Diagnostic tests & & & & \\
\hline Adj. R-squared & 0.6855 & & & \\
\hline Hansen $J$ statistic & 5.3387 & & & \\
\hline [p-value] & {$[0.2543]$} & & & \\
\hline Sargan $C$ statistic & 2.3840 & & & \\
\hline [p-value] & {$[0.4966]$} & & & \\
\hline Wald test & 13.2071 & & & \\
\hline [p-value] & {$[0.0215]$} & & & \\
\hline Autocorrelation & & GMM esti & are robus & \\
\hline Heteroscedasticity & & correlatio & Heterosce & \\
\hline Normality (JB test) & 0.9423 & & & \\
\hline [p-value] & [0.6243] & & & \\
\hline
\end{tabular}

Notes:

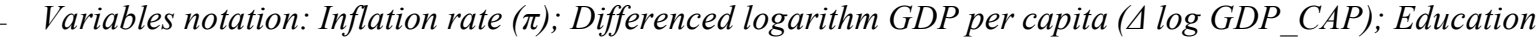
enrollment rate (ENROL); Differenced logarithm GFCF ( $\triangle$ log GFCF); Differenced logarithm government consumption ( $\triangle \log G O V$ CONS); the intercept $\left(\beta_{0}\right) . \Delta$ refers to the first-and second-difference operators.

- ***,**, and * denote the $0.01,0.05$, and 0.10 levels of significance, respectively.

- t-Statistics of the estimated coefficients are (in parentheses), whereas p-values of the post-estimation diagnostic tests are [in square brackets].

- We do not report results of autocorrelation and heteroscedasticity for the GMM different estimates since the GMM procedure is robust to them.

Regarding the control variables, GMM results reveal a statistically significant positive relationship, with a relatively high magnitude, between GDP per capita and education expenditure per student in Egypt at the 1\% significance level (equals $\beta_{2}=1.834$; p-value $<0.01$ ). That is, ceteris paribus, if GDP per capita increases by one percent, it is expected that education expenditure per student will increase by 1.834 percent. This result is also consistent with the economic theory and the literature; for example, Fernandez and Rogerson (1997), who find that the coefficient on income is highly statistically significant.

In our GMM model, we use education expenditure per student as a dependent variable, not total education expenditure in levels. Therefore, the education enrollment rate (as an independent variable) is expected to negatively affect education expenditure (per student), mirroring a decline in the individual student's share of the total education expenditure as the number of students enrolled increases. Table 6 reveals that the education enrollment rate shows the expected negative sign. The enrollment rate has a statistically significant negative impact on education expenditure per student at the $1 \%$ significance level (equals $\beta_{3}=-0.01296 ; p$-value $<0.01$ ). Holding all other explanatory variables constant, if the enrollment rate increases by one percent, it is expected that education expenditure per student will decrease by approximately 0.013 percent. This result is consistent with the literature, for example, Fernandez and Rogerson (1997).

Concerning the crowding-out effect among education expenditure and other rival government expenditures, GFCF shows the expected negative sign. That is, GFCF has a statistically insignificant negative impact on education expenditure per student at the $10 \%$ significance level (equals $\beta_{4}=-0.0556$; $p$-value $>0.1$ ). This result is consistent with the literature, for example, Saeki (2005), but it is not significant. In the same vein of the crowding-out effect among education expenditure and other rival government expenditures, GOV_CONS shows the expected negative sign. That is, GOV_CONS has a statistically insignificant negative impact on education expenditure per student at the $10 \%$ significance level (equals $\beta_{5}=-2.554 ; p$-value $>0.1$ ). This result is consistent with the literature, for example, Saeki (2005), but it is not significant. These two insignificant negative impacts of both GFCF and GOV_CONS on education expenditure in Egypt reveal no significant crowding-out effect among education expenditure and these two expenditure programs. 


\subsection{Diagnostic tests}

Based on the adjusted $\mathrm{R}^{2}$ value, the GMM can explain approximately $68.5 \%$ of the total variations in education expenditure in Egypt during the study period. The Sargan $C$ statistic $=2.38$; $p$-value $>0.1$. Therefore, we fail to reject its null hypothesis that our instrument set satisfies the orthogonality condition, indicating that our instruments are jointly valid (not correlated with the error term). Furthermore, the Hansen $J$ statistic of overidentification restriction $=5.34 ; p$-value $>0.1$. Accordingly, we fail to reject its null hypothesis, suggesting that our instruments are orthogonal to the error term, the overidentifying restrictions are valid, and our estimated GMM models are well-specified. To emphasize whether the estimated equation satisfies restrictions presupposed by economic and statistical theory, we use the Wald test (Hall, 2005, p. 200). Its $F$-statistic is under the null hypothesis that the coefficients on the explanatory variables are jointly restricted to zero. The joint Wald $F$-statistic $=13.21 ; p$-value $<0.01$. Therefore, we reject its null hypothesis that the coefficients on the explanatory variables are jointly restricted to zero. The regression residuals are normally distributed since we fail to reject the null hypothesis of the JB test. Its test statistic $=0.94 ; p$-value $>0.1$. In addition, the GMM models are robust to both autocorrelation and heteroscedasticity.

\section{Summary and concluding remarks}

This paper concentrated on the empirical evidence of the relationship between the inflation rate and education expenditure. To this end, the GMM model has been conducted. Moreover, many conventional unit root tests have been used to check the stationarity of the variables, alongside the Kapetanios unit root test with structural breaks. GMM estimates for the education expenditure model revealed that inflation plays a fundamental role in explaining education expenditure per student in Egypt. This result is consistent with the economic theory and the literature, e.g., Ihugba et al. (2019). Our results also revealed a statistically significant positive relationship, with a relatively high magnitude, between GDP per capita and education expenditure per student. Besides, we use education expenditure (per student) as a dependent variable. It showed the expected negative sign. These two findings align with the literature, for example, Fernandez and Rogerson (1997). Concerning the effect of both GFCF and GOV_CONS on education expenditure, results showed no significant crowding-out effect among education expenditure and these two rival expenditure programs in Egypt. These findings are in line with the literature, e.g., Saeki (2005). Lastly, our GMM estimates passed all the diagnostic tests. Finally, we suggest policymakers to keep inflation rates low to avoid their deleterious effects on education expenditure.

\section{References}

Altinger, L. P. (2002) Monetary policy reaction functions in transition economies acceding to the EU. London Business School (University of London).

Arellano, M. and Bond, S. R. (1991) "Some tests of specification for panel data: Monte Carlo evidence and an application to employment equations," The review of economic studies, 58(2), pp. 277-297.

Arellano, M. and Bover, O. (1995) "Another look at the instrumental variable estimation of error-components models," Journal of econometrics, 68(1), pp. 29-51.

Berg, I. (1981) "The Effects of inflation on and in higher Education," The ANNALS of the American Academy of Political and Social Science, 456(1), pp. 99-111.

Bond, S. R., Hoeffler, A. and Temple, J. R. W. (2001) GMM estimation of empirical growth models, Discussion Paper No. 2048, Centre for Economic Policy Research.

Bowen, W. G. (1975) "The Effects of Inflation/Recession on Higher Education.," in. The Regents 11th Annual Trustee Conference, March 13, 1975, New York Hilton Hotel.: ERIC.

Busemeyer, M. R. (2007) "Determinants of public education spending in 21 OECD democracies, 1980-2001," Journal of European Public Policy, 14(4), pp. 582-610.

Card, D. (1999) "The causal effect of education on earnings," Handbook of labor economics, 3, pp. 1801-1863.

Choi, I. (2015) Almost all about unit roots: Foundations, developments, and applications, Cambridge University Press. doi: 10.1017/CBO9781316157824.

Clarida, R., Galí, J. and Gertler, M. (1998) "Monetary policy rules in practice: Some international evidence," european economic review, 42(6), pp. 1033-1067.

Creamer, K. and Botha, R. T. (2017) "Assessing nominal GDP targeting in the South African context," Central Bank Review, 17(1), pp. 1-10.

Dickey, D. and Fuller, W. (1981) "Likelihood Ratio Statistics for Autoregressive Time Series with a Unit Root," Econometrica. doi: 10.2307/1912517.

Downes, A. S. (2001) "Education, productivity and the economic development of Barbados," Caribbean quarterly, 47(2-3), pp. 1-19.

Ege Yazgan, M. and Yilmazkuday, H. (2007) "Monetary policy rules in practice: evidence from Turkey and Israel,' Applied Financial Economics, 17(1), pp. 1-8.

Fernandez, R. and Rogerson, R. (1997) The determinants of public education expenditures: Evidence from the 
States, 1950-1990. National Bureau of Economic Research Cambridge, Mass., USA.

Guo, Y. and Alexander, W. R. J. (2006) "Expenditure uncertainty and savings in China: Evidence from provincial level data," in Japan Economic Policy Association (JEPA) International Conference: Asian Economic Initiative: How Do We Integrate Our How Do We Integrate Our Economies? University of the Sunshine Coast, Queensland. University of the Sunshine Coast, Queensland.

Hall, A. R. (2005) Generalized method of moments. Oxford university press.

Hamilton, J. D. (1994) Time series analysis. Princeton university press.

Han, F. (2012) Essays in Time Series Econometrics: Nonlinear, Nonstationary GMM Estimation, Credit Shock Transmission, and Global VAR Models. University of California, Berkeley.

Hansen, L. P. (1982) "Large sample properties of generalized method of moments estimators," Econometrica: Journal of the econometric society, pp. 1029-1054.

Hanushek, E. A. and Rivkin, S. G. (1996) Understanding the 20th century growth in US school spending. National Bureau of Economic Research Cambridge, Mass., USA.

Hong, Y. (2020) Foundations of Modern Econometrics: A Unified Approach. World Scientific.

Ihugba, O. A., Ukwunna, J. C. and Sandralyn, O. (2019) "Government education expenditure and primary school enrolment in Nigeria: An impact analysis," Journal of economics and international finance, 11(3), pp. 2437.

Judd, J. and Rudebusch, G. (1998) "Taylor's Rule and the Fed: 1970-1997," Economic Review-Federal Reserve Bank of San Francisco, pp. 3-16.

Juhn, G. and Mauro, P. (2002) Long-run determinants of exchange rate regimes: A simple sensitivity analysis. International Monetary Fund Washington, DC.

Juhro, S. M., Iyke, B. N. and Narayan, P. K. (2021) "Interdependence between monetary policy and asset prices in ASEAN-5 countries," Journal of International Financial Markets, Institutions and Money, 75, p. 101448.

Kapetanios, G. (2005) "Unit-root testing against the alternative hypothesis of up to m structural breaks," Journal of Time Series Analysis. doi: 10.1111/j.1467-9892.2005.00393.x.

Kennedy, P. (2008) A guide to econometrics. 6th ed. Blackwell Publishing Ltd.

Kwiatkowski, D. et al. (1992) "Testing the null hypothesis of stationarity against the alternative of a unit root," Journal of Econometrics. doi: 10.1016/0304-4076(92)90104-y.

Leszczensky, L. and Wolbring, T. (2019) "How to deal with reverse causality using panel data? Recommendations for researchers based on a simulation study," Sociological Methods \& Research, p. 0049124119882473.

Mátyás, L., Gourieroux, C. and Phillips, P. C. . (1999) Generalized method of moments estimation. Cambridge University Press.

Mavroeidis, S. (2005) "Identification issues in forward-looking models estimated by GMM, with an application to the Phillips curve," Journal of Money, Credit and Banking, 37(3), pp. 421-448.

Morgan, D. R., Kickham, K. and LaPlant, J. T. (2001) "State support for higher education: A political economy approach," Policy Studies Journal, 29(3), pp. 359-371.

Narayan, P. K., Narayan, S. and Smyth, R. (2009) "Understanding the inflation-output nexus for China," China Economic Review, 20(1), pp. 82-90.

Newey, W. K. and West, K. D. (1987) "Hypothesis testing with efficient method of moments estimation," International Economic Review, pp. 777-787.

Ng, S. and Perron, P. (2001) "Lag length selection and the construction of unit root tests with good size and power," Econometrica, 69(6), pp. 1519-1554.

Ogaki, M. (1993) "Generalized method of moments: Econometric applications," in Handbook of Statistics, vol. 11, ed. G.S. Maddala, C.R. Rao and H.D. Vinod. Elsevier.

Phillips, P. C. . and Perron, P. (1988) "Testing for a unit root in time series regression," Biometrika.

Ram, R. (1995a) "Defense expenditure and economic growth," Handbook of defense economics, 1, pp. 251-274.

Ram, R. (1995b) "Public educational expenditures in the United States: An analytical comparison with other industrialized countries," Economics of Education Review, 14(1), pp. 53-61.

Rodrik, D. (2008) “The real exchange rate and economic growth," Brookings papers on economic activity, 2008(2), pp. $365-412$.

Roodman, D. (2009a) "A note on the theme of too many instruments," Oxford Bulletin of Economics and statistics, 71(1), pp. $135-158$.

Roodman, D. (2009b) "How to do xtabond2: An introduction to difference and system GMM in Stata," The stata journal, 9(1), pp. 86-136.

Saeki, M. (2005) "Systematic, Political, and Socioeconomic Influences on Educational Spending in the American States 1," Review of policy research, 22(2), pp. 245-256.

Sagarik, D. (2013) "An Analysis of the Determinants of Education Expenditure in Thailand," Asian Politics \& Policy, 5(2), pp. 227-248.

Sargan, J. D. (1958) "The estimation of economic relationships using instrumental variables," Econometrica: 
Journal of the Econometric Society, pp. 393-415.

Sargan, J. D. (1959) "The estimation of relationships with autocorrelated residuals by the use of instrumental variables," Journal of the Royal Statistical Society: Series B (Methodological), 21(1), pp. 91-105.

Sequeira, T. N. (2021) "Inflation, economic growth and education expenditure," Economic Modelling, p. 105475.

Shrestha, M. B. and Bhatta, G. R. (2018) "Selecting appropriate methodological framework for time series data analysis," The Journal of Finance and Data Science, 4(2), pp. 71-89.

Stock, J. H. and Watson, M. (2020) Introduction to econometrics. Fourth edi. Pearson New York.

Swan, E. (1967) "Monetary policy and the financing of higher education."

Ullah, S., Akhtar, P. and Zaefarian, G. (2018) "Dealing with endogeneity bias: The generalized method of moments (GMM) for panel data," Industrial Marketing Management, 71, pp. 69-78.

Wooldridge, J. M. (2001) "Applications of generalized method of moments estimation," Journal of Economic perspectives, 15(4), pp. 87-100.

Wooldridge, J. M. (2020) Introductory econometrics: A modern approach. 7th ed. Cengage Learning, Inc.

Yilmazkuday, H. (2013) "Inflation thresholds and growth," International Economic Journal, 27(1), pp. 1-10.

Yun, W. S. and Yusoff, R. (2018) "The determinants of public education expenditure in Malaysia," Jurnal Ekonomi Malaysia, 52(2), pp. 109-122.

Zhang, S. and Ou, S.-H. (2013) "The impact of inflation on expenditures and happiness in China," Journal of chinese economics, 1(1). 